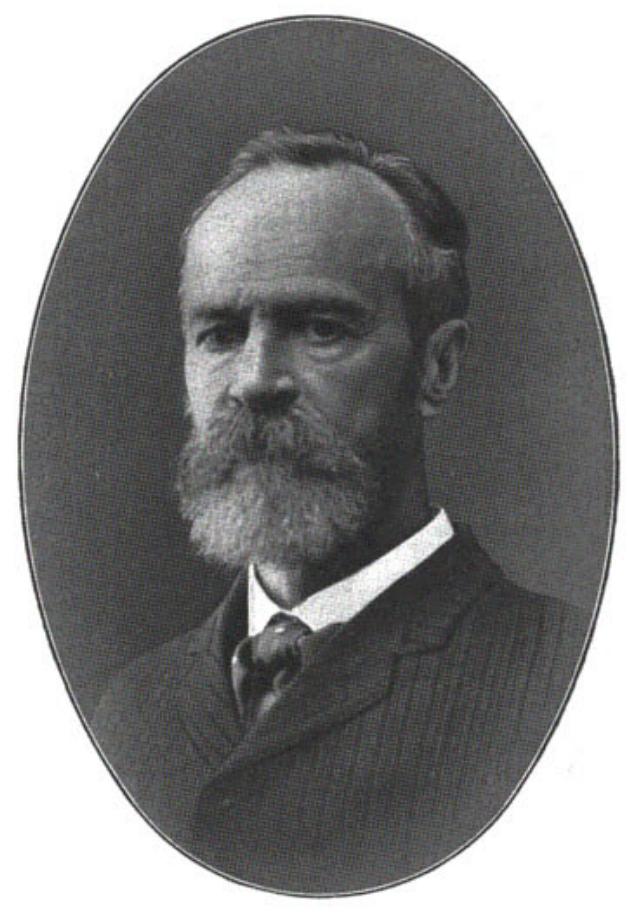

Throfanes

Verlag von VEIT \& COMP. in Leipzig. 



\section{Émile Boutroux}

\section{WILLIAM JAMES}

Mit einem Brief des Verfassers an den Übersetzer und zwei Abhandlungen des Verfassers

Die Bedeutung der Geschichte der Philosophie für das Studium der Philosophie und

Gegenstand und Methode der Geschichte der Philosophie

Autorisierte deutsche Ausgabe von Dr. Bruno Jordan

Mit einem Bildnis von William James

Verlag von Veit \& Comp., Leipzig 1912 
Druck von Metzger \& Wittig in Lelpzig 